\title{
Peningkatan Mutu Madrasah melalui Modal Sosial
}

\author{
Ju'subaidi \\ Sekolah Tinggi Agama Islam Negeri Ponorogo
}

\begin{abstract}
This paper attempts to examine the important role of social capital in the meninges-forces madrasah education quality. Madrasah as national education subsystem has a heavy burden in carrying out the mandate of the law. The biggest problem is the activity of improving the quality of education that is determined by the achievement of the ultimate goal of education effectively and more efficiently. That goal is the realization of academic ability, moral and social. Structure and values of the communities around it is actually a social capital that should be used by the madrassa to improve the quality of education. Social capital is a means of achieving national education goals.
\end{abstract}

Keywords: $\quad$ madrasas, National Education Standards (NES), social capital.

\begin{abstract}
Abstrak
Tulisan ini mencoba mengkaji peran penting modal sosial dalam peningkatan mutu pendidikan madrasah. Madrasah sebagai subsistem pendidikan nasional memiliki beban yang berat dalam mengemban amanat undang-undang. Problem terbesar adalah kegiatan meningkatkan mutu pendidikan yang ditentukan oleh ketercapaian tujuan akhir pendidikan secara efektif dan lebih efisien. Tujuan itu adalah terwujudnya kemampuan akademik, moral dan sosial. Struktur dan nilainilai yang dimiliki masyarakat sekitar sebenarnya merupakan modal sosial yang seharusnya dimanfaatkan oleh madrasah untuk meningkatkan mutu pendidikannya. Modal sosial ini menjadi sarana mencapai tujuan pendidikan nasional.
\end{abstract}

Kata kunci: madrasah, Standar Nasional Pendidikan (SNP), modal sosial. 


\section{A. Pendahuluan}

Percepatan informasi dan teknologi sebagai ciri era globalisasi telah mempengaruhi orientasi pendidikan Indonesia dari nasional ke internasional sehingga dunia pendidikan di Indonesia dihadapkan pada berbagai persoalan. Misalnya, belum meratanya pendidikan, rendahnya kualitas lulusan yang dihasilkan sekolah dan madrasah, rendahnya daya saing pendidikan di tingkat regional nasional maupun internasional, dan rendahnya daya saing di pasar kerja Asean. Kondisi ini didukung adanya fakta yang menjelaskan bahwa dalam hal daya saing, Indonesia menduduki peringkat ke-45 dari 47 negara. Sedangkan, Singapura berada pada peringkat ke-2 dan Malaysia serta Thailand masing-masing pada urutan ke-25 dan ke-23. Terkait masalah produktivitas, terungkap bahwa produktivitas sumberdaya manusia Indonesia sangat rendah, hal tersebut setidaknya dikarenakan kurangnya kepercayaan diri, kurang kompetitif, kurang kreatif dan sulit berprakarsa sendiri (self-starter). Itu semua disebabkan oleh sistem pendidikan yang kurang mengembangkan inovasi dan kreativitas. ${ }^{1}$

Mutu pendidikan memang merupakan persoalan yang sangat krusial. Semua bangsa memandang penting hal ini. Sekolahsekolah di Amerika Serikat misalnya selalu menilai mutu sekolah dengan menghitung berapa persen lulusan sekolah tersebut diterima di perguruan tinggi favorit. Perguruan tinggi, mereka dinilai oleh masyarakat dengan menghitung berapa persen lulusannya menduduki jabatan strategis di lembaga pemerintahan dan perusahaan bergengsi. ${ }^{2}$

Peningkatan mutu sekolah secara massal merupakan suatu upaya untuk menciptakan dan menjamin proses perubahan berlangsung secara terus menerus dan dapat dilaksanakan oleh semua sekolah. Sekolah atau madrasah memiliki latar belakang dan potensi yang berbeda yang menyebabkan tidak mungkin diterapkannya satu kebijakan untuk semua sekolah "one size fits for all policy". Sehingga kebijakan dan upaya peningkatan mutu sekolah dan madrasah seharusnya memiliki fleksibilitas yang

${ }^{1}$ Siti Irene Astuti Dwiningrum, Desentralisasi Pendidikan dan Dinamika Sosial, (Yogyakarta: Pascasarjana Sosiologi UGM, 2009), hlm. 31.

${ }^{2}$ Ben Angger, Teori sosial kritis: Kritik, Penerapan dan Implikasinya (terj), (Yogyakarta: Pustaka Pelajar, 2006), hlm. 22. 
tinggi. Akan tetapi, harus tetap ada dimensi kebijakan yang bersifat imperatif bagi semua sekolah dan madrasah.

Oleh karena itu, masing-masing sekolah maupun madrasah memiliki problem yang unik, keunikannya terletak pada adanya perbedaan latar belakang dan karakteristik masing-masing. Di antara problem madrasah adalah adanya kecenderungan meninggalkan budaya pesantren sebagai induknya, lebih disebabkan oleh tuntutan perubahan dan standarisasi. Azyumardi Azra menyebut situasi tersebut dengan istilah "krisis epistemologi". ${ }^{3}$ Jika madrasah ingin survive atau terlindas oleh perubahan, maka sangat tergantung pada kemampuan madrasah dalam mengembang diri, mengidentifikasi berbagai persoalan sekaligus mencari pemecahannya. ${ }^{4}$ H.A.R. Tilaar menjelaskan bahwa problem yang dihadapi madrasah dan pesantren justru berasal dari keunikannya yaitu lembaga yang tumbuh dari lapisan bawah masyarakat. ${ }^{5}$ Di tengah-tengah pertumbuhannya dari masyarakat yang secara ekonomis berada pada level menengah ke bawah, menjadikan madrasah serba sulit. Keadaan ini telah melahirkan suatu sikap defense mechanism untuk mengungkung diri dari pengaruh luar. Pengelolaan madrasah yang berorientasi kepada masyarakat telah mengakibatkan keanekaragaman pengelolaan sehingga sulit untuk dicarikan standar peningkatan mutu. Oleh karenanya dalam rangka mengatasi problem peningkatan mutu pendidikan yang dihadapi madrasah diperlukan pendekatan yang relevan dengan situasi dan kondisi yang terjadi di madrasah, salah satunya melalui pemanfaatan modal sosial (social capital) yang dimiliki madrasah.

\section{B. Definisi Mutu Madrasah}

Istilah mutu secara definitif bervariasi. Dalam kamus populer mutu disinonimkan dengan kualitas. ${ }^{6}$ Menurut Nomi Pfeffer dan Anna Coote menyatakan bahwa "mutu merupakan konsep yang

${ }^{3}$ Azumardi Azra, Pendidikan Islam; Tradisi dan Modernisasi Menuju Millennium Baru, (Ciputat: Logos, 2000), hlm. 39.

${ }^{4}$ Choirul Fuad Yusuf, Isu-Isu Sekitar Madrasah, (Jakarta: Puslitbang Pendidkan Agama \& Keagamaan, 2006), hlm. 15.

5 H.A.R. Tilaar, Paradigma Pendidikan Nasional, (Bandung: Rineka Cipta, 2004), hlm. 153.

${ }^{6}$ Pius A Partanto dan M. Dahlan, Kamus Ilmiah Popular, (Surabaya: ARKOLA, 1994), hlm. 505. 
licin". 7 Penyataan Nomi tersebut mengisyaratkan adanya perbedaan pemahaman terhadap kata "mutu" yang tergantung pada siapa yang memaknainya. Terlebih jika "mutu" dikaitkan dengan kata-kata lain misalnya penjaminan mutu (quality assurance), mutu tinggi (top quality), kontrol mutu (control quality), mutu terpadu (total quality) dan lain sebagainya. Jika demikian berarti mutu merupakan konsep atau gagasan yang bersifat dinamis, tergantung pada pengguna dan penggunaannya. Mutu juga dipandang sebagai konsep yang bersifat absolut dan relatif.

Sebagai sebuah konsep yang absolut, mutu dalam perbincangan masyarakat sehari-hari identik dengan kata baik, benar. Dalam definisi yang absolut, sesuatu yang bermutu merupakan bagian dan standar yang sangat tinggi yang tidak dapat disaingi. Misalnya, produk-produk yang bermutu adalah barang yang dibuat bersifat sempurna dan dengan biaya yang mahal sehingga membuat pengguna (user) produk-produk tersebut bangga dan berbeda dengan orang lain.

Apabila dikaitkan dengan konteks pendidikan, maka mutu dapat berarti tinggi atau elit, karena lembaga pendidikan yang memiliki sifat elit hanya dimiliki sebagian kecil dari lembaga atau institusi pendidikan yang mampu memberikan pengalaman pembelajaran yang tinggi kepada para peserta didiknya.

Sedangkan kata mutu sebagai konsep yang relatif dalam Total Quality Management merupakan konsep yang dianggap muncul dari suatu produk atau layanan bukan atribut suatu produk. Mutu dalam sebuah layanan dinyatakan ada apabila sebuah layanan tersebut memenuhi spesifikasi yang ada. Oleh karena itu, mutu tidak harus mahal dan bersifat eksklusif. Konsep mutu dalam makna relatif akan memiliki dua dimensi, pertama, sesuai dengan spesifikasi. Kedua, memenuhi kebutuhan pengguna (user). Hal yang pertama dalam kontekss Total Quality Management merupakan mutu yang sesungguhnya (quality in fact). Artinya suatu produsen memproduksi secara konsisten sesuai dengan standar atau spesifikasi yang dibakukan, misalnya standar internasional yang diistilahkan dengan ISO9000. Sedangkan dimensi yang kedua adalah mutu yang diinterpretasikan oleh

${ }^{7}$ Edward Sllis, Total Quality Managemen in Education, Manajemen Mutu Pendidikan terj.(Yogyakarta: ITCiSoD, 2010), hlm. 50. 
pelanggan, dalam konteks TQM mutu merupakan sesuatu yang dapat memuaskan, melampaui keinginan dan memenuhi kebutuhan pelanggan. Mutu versi kedua ini dikenal dengan sebutan quality in perception.

Quality in perception (mutu versi pelanggan/pengguna) ini menjadi penting artinya dalam menentukan kesuksesan suatu produk atau layanan jasa, sehingga menjadi hal yang harus diberi perhatian lebih, mengingat pengaruhnya terhadap penggunaan produk oleh pelanggan akan meningkat dan dampak pengiring terhadap meningkatnya motivasi karyawan juga dapat diwujudkan, meminjam istilah yang dikemukakan oleh Tom Peters dalam buku Edward Sallis tentang TQM “ pelanggan jauh lebih penting dibandingkan harga dalam menentukan permintaan barang dan jasa". ${ }^{\circ}$ Dengan kata lain, seorang produsen atau layanan jasa seharusnya memusatkan perhatiannya terhadap tanggapantanggapan pelanggan untuk tetap survive di tengah pelanggan.

Sama halnya dengan kata mutu yang dikaitkan dengan sekolah atau madrasah yang memiliki banyak makna. Definisi tunggal kualitas sekolah yang diterima banyak pihak yang sulit untuk merumuskan. Apalagi, jika rumusan definisi mutu sekolah dikaitkan dengan tujuan dan strategi pendidikan yang ada. Begitu pula kualitas sekolah dipersepsikan berbeda-beda menurut pandangan kepala sekolah, guru, siswa dan orang tua siswa.

Jika makna mutu hanya diartikan sebagai kemampuan penguasaan pengetahuan merupakan suatu realitas. Secara sadar dan terencana kondisi ini harus diubah. Perubahan dalam kaitan dengan mutu ini merupakan keharusan, khususnya apabila dikaitkan dengan masa depan, era baru abad 21. Siapa pun yang tidak mau berubah akan menjadi terasing dan tertinggal zaman.

Seorang ahli pendidikan, Michael Fullan (1994), menegaskan bahwa perubahan tidak dapat dihindarkan. Banyak pendidik terbawa arus perubahan masa depan, dengan berbagai euphoria, tetapi tidak menyadari masa depan itu sendiri, dengan lebih senang mempertahankan status quo. Fullan mengingatkan bahwa "yesterday's scores will not win tomorrow's ball games." Oleh karena itu, "if you are not part of the future, you're history!".

Berkaitan dengan perubahan di dunia pendidikan, futurist Alvin Toffler (1999) menegaskan bahwa: "The illiterate of the

\footnotetext{
${ }^{8}$ Sllis, Total Quality Managemen in Education ..., hlm. 57.
} 
21 st century will not be those who cannot read and write, but those who cannot learn, unlearn, and relearn." Pendidikan berfungsi untuk mempersiapkan generasi baru mampu hidup dan sukses menjalani kehidupan di masa depan, maka sekolah harus memahami dan mengidentifikasi kompetensi apa yang diperlukan untuk masa depan itu.

UNESCO menekankan pada empat pilar sebagai kemampuan dasar yang harus dihasilkan oleh dunia pendidikan. Keempat pilar tersebut adalah: a)learning to do (solve daily problems); b)learning to know (keep learning); c)learning to be (ethically responsible) and d)learning to live together (the ability to respect and work with others).

Menurut Kay (2008) sekolah harus mempersiapkan siswa dengan kemampuan: a) kesadaran global, b) watak kemandirian, c) kemampuan bekerjasama secara global, d) kemampuan menguasai ITC, e) kemampuan melek teknologi, f) kemampuan intelektual yang ditekankan pada critical thinking dan kemampuan memecahkan masalah, g) kemampuan untuk melakukan inovasi \& menyempurnakan, dan, h) memiliki pengetahuan dan keterampilan yang bersifat fleksibel dan dinamis.

Selanjutnya, Kay mengidentifikasi 5 (lima) kemampuan yang amat penting dalam kehidupan, yakni; a) etika kerja, b) kemampuan berkolaborasi, c) kemampuan berkomunikasi, d) tanggung jawab sosial dan, e) berpikir kritis dan memecahkan masalah. Perkembangan dan perubahan kehidupan masyarakat mengarah pada satu tren besar dan universal, yakni perubahan dan kemajuan.

Sebagai negara terbuka, bangsa Indonesia akan masuk arus besar tersebut. Pengalaman perkembangan teknologi selama ini menunjukkan tingkat perkembangan yang terjadi amat cepat dan dampaknya juga cepat menyebar dalam berbagai aspek kehidupan termasuk dalam aspek kultur. Oleh karena itu, bangsa Indonesia harus mempersiapkan diri dengan baik dan masuk arus perubahan dengan cerdas agar bisa memanfaatkan peluang yang ada, tidak sekedar memperoleh dampak negatif belaka.

Kompetensi abad ke 21 harus pula dijadikan acuan dalam pendidikan Indonesia. Sekolah, khususnya kepala sekolah dan guru harus mulai mengubah mind-set-nya. Mengajar tidak sekedar mentransfer ilmu pengetahuan, teknologi dan keterampilan, 
melainkan mengajar juga mentransfer kehidupan. Implikasi yang paling dekat adalah semua guru, tidak pandang mata pelajaran yang diampu, memiliki tanggung jawab yang sama dalam membangun moral dan karakter siswa. Dengan kata lain membangun karakter atau watak merupakan tujuan utama dalam proses pembelajaran. Tapi sayangnya pengembangan karakter tidak bisa diajarkan, melainkan dikembangkan lewat proses pembiasaan. Oleh karena itu, perilaku guru harus bisa dijadikan teladan bagi para siswanya dan sekolah harus menjadi kancah pembangunan karakter (Character building).

Secara mendasar sekolah memang harus ditekankan untuk membangun karakter siswa dan sebagai basis membangun karakter bangsa. Oleh karena itulah visi pendidikan nasional Indonesia menekankan keberadaan manusia berkualitas dalam kecendekiawanan, cerdas spiritual, emosional, dan sosial, serta kinestetik (gerak tubuh) dan kepiawaian, serta mampu menghadapi perkembangan dan persaingan global. Untuk ini, sekolah harus mulai mengembangkan kompetensi yang menekankan pada pengembangan karakter.

\section{Modal Sosial}

Penjelasan tentang modal sosial meliputi; pengertian modal sosial, bentuk-bentuk modal sosial, peran modal sosial dalam pendidikan dan modal sosial madrasah.

1. Pengertian Modal Sosial

Pembahasan tentang modal sosial, pada awalnya digunakan untuk menjelaskan hubungan timbal balik dan sistem sosial. Hubungan timbal balik tersebut melahirkan struktur sosial dan berbagai relasi sosial. Relasi-relasi sosial tersebut dilihat sebagai sumber atau modal bagi individual atau kelompok sebagai komponen struktur sosial yang penting. Loury dalam James S. Coleman mendefinisikan modal sosial sebagai kumpulan sumber yang melekat dalam relasi keluarga dan dalam organisasi sosial dan bermanfaat untuk perkembangan kognitif dan sosial bagi anak-anak atau pemuda. $^{9}$

${ }^{9}$ James S. Colman, Foundations of Social Theory, (Harvard University: The Belknap Press, 1994), hlm. 368. 
Berbagai relasi tersebut di dalamnya memuat relasi wewenang dan relasi kepercayaan serta norma-norma yang diyakini dan dianut oleh sekelompok manusia. Modal sosial, pada gilirannya, tercipta ketika relasi antara orang-orang mengalami perubahan sesuai dengan cara yang memudahkan tindakan. ${ }^{10}$ Modal manusia tidak berwujud, namun dapat diwujudkan dalam bentuk keterampilan dan pengetahuan yang dipelajari oleh individu. Modal sosial juga tidak berwujud, namun dapat diwujudkan dalam bentuk relasi di antara individu-individu. Jadi baik modal manusia maupun modal sosial dalam sebuah dinamika yang saling melengkapi. Sementara itu menurut Leksono istilah modal sosial (social capital) pertama kali dikenalkan oleh Lyda Judson Hanifan di tahun 1916 dalam sebuah diskusi tentang upaya membangun pusat pembelajaran masyarakat. ${ }^{11}$

Istilah modal sosial (social capital) juga digunakan untuk menganalisis masalah perkembangan ekonomi dalam sebuah kota, hal ini sebagaimana dilakukan oleh ekonom Glenn Loury dan sosiolog Ivan Light. Dijelaskan oleh Loury dalam dalam James S. Coleman di pasar sentral Cairo, batas antara pedagang sulit diketahui oleh orang luar. Pemilik toko yang khusus menjual kulit, ketika ditanya tentang di mana dapat ditemukan jenis perhiasan tertentu, akan menunjukkan bahwa tokonya juga menjual perhiasan atau barang mirip perhiasan tertentu, karena memiliki teman dekat yang menjual perhiasan tersebut. ${ }^{12}$ Untuk memperoleh gambaran, apa sebenarnya yang dimaksud dengan modal sosial (social capital), berikut akan dijelaskan beberapa pengertian tentang modal sosial menurut para ahli.

John Field menyebutkan bahwa teori modal sosial, pada intinya merupakan teori yang menjelaskan tentang soal hubungan sosial. Dengan membangun hubungan sesama manusia dan menjaganya agar terus berlangsung sepanjang waktu, orang akan mampu bekerja bersama-sama untuk

${ }^{10}$ Colman, Foundations of Social Theory ..., hlm. 369.

${ }^{11}$ S. Laksono, Runtuhnya Modal Sosial, Pasar Tradisional; Perspektif Emik Kualitatif, (Malang: Citra Malang, 2009), hal, 36.

${ }^{12}$ Colman, Foundations of Social Theory ...., (Harvard University: The Belknap Press, 1994), hlm. 372. 
mencapai berbagai hal yang tidak dapat mereka lakukan sendirian. ${ }^{13}$

Sedangkan Fukuyama dalam Leksono (2009) menyebutkan, modal sosial adalah sekumpulan nilai informal atau norma yang menyebar di antara anggota kelompok yang memungkinkan kerjasama terjadi di antara mereka. Kerjasama tersebut terjadi apabila antar anggota kelompok masyarakat tersebut memenuhi apa yang diharapkan antar mereka bahwa lainnya akan bertingkahlaku dengan dapat diandalkan dan memiliki kejujuran, kemudian mereka saling mempercayai satu sama lain.

Dalam pendapat yang berbeda, C. Grotaert dalam Lawang "kapital sosial adalah institusi, hubungan, sikap dan nilai yang membimbing interaksi di antara manusia dan memberikan kontribusi pada perkembangan ekonomi dan sosial".

Putman (1999) mendefinisikan modal sosial adalah sebagai bagian dari kehidupan sosial, jaringan, norma, dan kepercayaan yang mendorong partisipan bertindak bersama secara lebih efektif untuk mencapai tujuan-tujuan bersama.

Selain itu, Bourdieu dalam John Field menjelaskan bahwa modal sosial sebagai modal hubungan 'dukungan-dukungan' bermanfaat: modal harga diri dan kehormatan yang seringkali diperlukan jika orang ingin menarik para klien dalam posisi yang penting secara sosial dan yang bisa menjadi alat tukar, misalnya dalam karier politik.

Sedang menurut Newton dalam Leksono modal sosial memuat 3 unsur: 1) norma dan nilai, 2) jaringan atau organisasi/ kelembagaan, dan 3) konsekuensinya atau akibatnya. ${ }^{14}$ Dari beberapa definisi tentang modal sosial di atas dapat ditarik benang merah bahwa modal sosial mempunyai gagasan sentral, jaringan sosial merupakan aset yang sangat bernilai. Jaringan sosial merupakan aset yang sangat berharga. Jaringan memberikan kohesi sosial karena mendorong orang bekerjasama satu sama lain, tidak sekedar dengan orang yang hlm.1.

13 John Field, Modal Sosial (terj.) (Bantul: Kreasi Wacana, 2010),

${ }^{14}$ Laksono, Runtuhnya modal ..., (Malang: Citra Malang, 2009), hal, Xxxv. 
mereka kenal secara langsung- untuk memperoleh manfaat timbal balik.

\section{Bentuk-Bentuk Modal Sosial}

Penggunaan konsep modal sosial akan mengungkapkan bahwa pada dasarnya konsep ini memuat penjelasan tentang relasi sosial dan fungsinya. Nilai konsep tersebut terletak pada fakta bahwa modal sosial mengidentifikasi beberapa aspek struktur sosial dan fungsinya. Fungsi struktur sosial yang diidentifikasi oleh konsep modal sosial adalah nilai aspek struktur sosial bagi para pelaku sebagai sumber yang dapat digunakan oleh para pelaku untuk merealisasikan kepentingannya. Sebagai contoh, sebuah penelitian yang dikemukakan oleh James. S. Coleman mengelompokkan studi rahasia mahasiswa radikal di Korea Selatan sebagai penyusun modal sosial yang dapat digunakan mahasiswa-mahasiswa tersebut dalam aktivitas revolusionernya menegaskan bahwa kelompok tersebut merupakan sumber yang menggerakkan mahasiswa dari protes individual menjadi pemberontakan yang terorganisir. ${ }^{15}$ Dari kasus ini nampak bahwa adanya kesamaan nilai yang diyakini oleh mahasiswa secara individual dengan kelompok organisasi mahasiswa telah memenuhi kesamaan fungsi sehingga dapat menggerakkan terjadinya tujuan revolusioner yang dilakukan mahasiswa secara massal.

Contoh lain, sebuah pengamatan yang dilakukan oleh Sodiq A. Kuntoro (2010) tentang bagaimana modal sosial dan modal kultural yang dikembangkan oleh masyarakat Jepang melalui sekolah telah mempengaruhi kehidupan masyarakat Jepang secara umum. Sekolah-sekolah di Jepang dikembangkan dengan menggunakan modal sosial dan budaya. Kehidupan sosial budaya di sekolah-sekolah Jepang lebih tampak dan menjadi kekuatan yang menonjol dikembangkan untuk mencapai perbaikan kualitas sekolah dibanding pengembangan ilmu pengetahuan teknik dan peralatan teknologi, walaupun hal tersebut tetap diperhatikan.

Menurut pengamatan Sodiq A. Kuntoro, masyarakat Jepang dapat dikatakan lebih mengutamakan modal sosial dan

15 Colman, Foundations..., (Harvard University: The Belknap Press, 1994), hlm. 374. 
budaya untuk mencapai kemajuan bangsanya. Pendidikan untuk membangun kehidupan sosial-budaya yang baik telah menjadi tujuan utama pendidikan di Jepang. ${ }^{16}$ UndangUndang Dasar pendidikan Jepang menetapkan bahwa tujuan pendidikan adalah "penyempurnaan karakter individu". Penggunaan modal sosial dan budaya oleh masyarakat Jepang untuk membangun kehidupan yang lebih baik di sekolah, keluarga, masyarakat dan tempat kerja.

Modal sosial telah menggerakkan kehidupan sekelompok masyarakat di atas, Oleh James S. Coleman dipilah menjadi nilai-nilai dan norma, relasi sosial dan struktur organisasi. ${ }^{17}$

a. Nilai-nilai dan Norma

Norma atau nilai-nilai yang diyakini oleh sebuah komunitas merupakan modal sosial. Pembahasan tentang norma dalam hal ini adalah norma preskriptif di mana norma ini sangat diperlukan dalam kehidupan bersama. Menurut James S. Coleman, norma preskriptif merupakan norma yang membuat seseorang melepaskan kepentingan diri sendiri untuk bertindak demi kepentingan kolektivitas. ${ }^{18}$ Dalam beberapa kasus norma tersebut diinternalisasikan dalam kehidupan bermasyarakat melalui penghargaan eksternal untuk tindakan-tindakan tanpa pamrih dan penolakan terhadap tindakan-tindakan yang egois. Tetapi norma ini akan dapat berfungsi dengan baik jika diikuti oleh sanksi internal maupun eksternal. Norma atau nilai-nilai dapat dihubungkan dengan modal sosial yang lain yakni kewajiban dan ekspektasi. ${ }^{19}$ Willmot dan Young juga menjelaskan, terdapat nilai-nilai yang berlaku dalam struktur masyarakat tertentu "selalu ada orangorang yang melakukan sesuatu untuk kepentingan orang lain". ${ }^{20}$ Tetapi di antara mereka ada nilai yang saling mengikat dan harus dipatuhi secara bersama.

Terdapat dua elemen kritis pada bentuk modal sosial ini yaitu tingkat kredibilitas lingkungan sosial yang berarti

16 Sodiq A. Kuntoro, Modal Sosial dan Budaya Bagi Peningkatan Kualitas Pendidikan Persekolahan, (Yogyakarta: PPS UNY, 2010), hlm. 5.

${ }^{17}$ Colman, Foundations of Social Theory ..., hlm. 375-388.

${ }^{18}$ Colman, Foundations of Social Theory ..., hlm. 381.

${ }^{19}$ Colman, Foundations of Social Theory ..., hlm. 375.

${ }^{20}$ Colman, Foundations of Social Theory ..., hlm. 375. 
bahwa kewajiban akan dilunasi dan tingkat kewajiban aktual tersebut dipegang. Struktur sosial yang berbeda akan menghasilkan nilai kredibilitas yang berbeda pula. Kasus yang menggambarkan nilai kredibilitas tersebut adalah asosiasi kredit berputar yang dijumpai di wilayah Asia Tenggara, khususnya Indonesia. Asosiasi ini adalah kelompok teman dan para tetangga secara khusus bertemu setiap bulan; setiap orang memberikan kontribusi sejumlah uang yang sama, kemudian uang tersebut diberikan pada salah satu anggota asosiasi tersebut melalui penawaran atau dengan lotre. Pemberian secara bergulir hingga semuanya mendapatkan sejumlah uang yang sama.

Menurut Geertz, asosiasi ini menjadi institusi yang efisien untuk menabung guna pengeluaran modal yang kecil, bantuan yang penting untuk perkembangan ekonomi. ${ }^{21}$ Tanpa tingkat kredibilitas yang tinggi di antara para anggota kelompok, asosiasi kredit semacam ini tidak akan ada karena orang yang menerima pembayaran uang pada awal urutan pertemuan dapat melarikan diri, membiarkan anggota lain rugi. Mengapa dalam sebuah asosiasi perlu diciptakan kewajiban melakukan kebaikan yang saling mengikat ?. Karena dengan kewajiban akan terbiasa terbangun saling tolong menolong.

b. Relasi sosial

Istilah relasi sosial digunakan untuk menjelaskan hubungan antar individu, atau individu dengan kelompok, atau individu dengan kelompok masyarakatnya. Terdapat definisi yang menjelaskan pengertian relasi sosial/ hubungan sosial yaitu hubungan sosial yang menunjukkan adanya interaksi antar individu, individu dengan kelompok, dan kelompok dengan kelompok yang dinamis yang menghasilkan perubahan".

Ada syarat yang diperlukan terjadinya relasi sosial/ hubungan sosial:

1) Adanya kontak sosial, hal ini tidak harus melulu terjadi melalui adanya sentuhan fisik. Klasifikasi kontak sosial dapat dijelaskan berdasarkan proses berlang-

${ }^{21}$ Colman, Foundations of Social Theory ...., hlm. 175. 
sungnya kontak sosial, baik kontak primer maupun skunder.

2) Adanya komunikasi, yakni adanya tanggapan atau reaksi seseorang terhadap suatu tindakan tertentu dari orang lain. Relasi sosial merupakan salah satu bentuk modal sosial. Terdapat istilah yang diperkenalkan oleh Ben-Porath dalam James S. Coleman (2008) untuk menjelaskan pentingnya relasi sosial dengan istilah relasi $-\mathrm{F}$. Relasi $-\mathrm{F}$ terdiri atas keluarga, teman dan relasi yang diupayakan. Sebuah artikel yang ditulis di halaman International Herald Tribune pada 21-22 Juni 1986, menjelaskan aktivis mahasiswa radikal di Korea Selatan. Artikel tersebut menggambarkan perkembangan pemikiran radikal yang dikirimkan dalam "kelompok-kelompok studi rahasia", bersumber dari kelompok mahasiswa yang berasal dari sekolah lanjutan yang sama atau kota asal yang sama atau gereja yang sama. Berbagai kesamaan tersebut menimbulkan relasi sosial yang pada akhirnya menjadi organisasi dasar demonstrasi dan protes-protes lainnya. Bentuk modal sosial lain yang mempunyai hubungan secara konseptual dengan relasi sosial adalah potensi informasi. Informasi sangat diperlukan untuk mendasari tindakan.

Dari deskripsi di atas, dapat dijelaskan bahwa relasi sosial mempunyai peran penting untuk mendapatkan informasi. Sehingga dengan potensi informasi yang diperoleh, seseorang atau kelompok organisasi dapat memanfaatkannya untuk kepentingan pencapaian tujuan.

\section{Organisasi/struktur Sosial}

Menurut James. S Coleman terdapat dua jenis organisasi sosial yakni organisasi sosial yang dapat disesuaikan dan organisasi sosial yang disengaja. Pertama, organisasi sosial yang disengaja adalah organisasi sosial yang didirikan untuk satu rangkaian tujuan tertentu juga dapat membantu tujuan lainnya. Oleh karena itu, organisasi sosial ini dapat dikategorikan sebagai bagian dari bentuk modal sosial.

Bentuk organisasi sosial yang kedua adalah organisasi sosial yang tidak disengaja. Penggunaan konsep ini dapat dilihat dari keberadaan hasil yang diperoleh dari keikutsertaan 
dan investasi yang dilakukan oleh para anggota organisasi sosial tersebut.

4. Peran Modal Sosial dalam Pendidikan

Fukuyama dalam Laksono menjelaskan bahwa norma merupakan bagian dari modal sosial yang proses pembentukannya tidak diciptakan oleh birokrat atau pemerintah, melainkan terbentuk melalui tradisi, sejarah dan

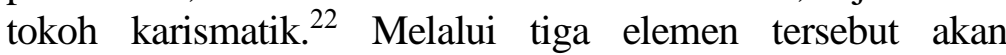
terbangun suatu tata cara prilaku seseorang atau sekelompok masyarakat, kemudian di dalamnya timbul modal sosial secara sporadis dalam kerangka menentukan tata cara atau aturan yang dapat mengukur kepentingan pribadi dan kepentingan kelompok.

Coleman (2010) juga menjelaskan bahwa antara modal sosial dengan modal manusia saling berhubungan. Modal sosial sebagai sumber yang bermanfaat yang tersedia bagi aktor melalui hubungan sosialnya.

Bagaimana modal sosial dapat mencapai hasil yang diharapkan? Coleman menyatakan bahwa agar modal sosial menjadi sumber modal bagi kehidupan bersama, maka perlu disepakati kewajiban dan harapan antar aktor, membangun kejujuran di lingkungan sosial, membuka saluran informasi dan menetapkan norma yang menopang bentuk-bentuk perilaku tertentu sambil menerapkan sanksi pada calon penunggang bebas (kelompok oppurtunis) terhadap modal sosial yang telah dibangun secara bersama-sama. Berbeda dengan Coleman, Fukuyama mendefinisikan modal sosial sebagai berikut:

Social capital a set of informal values or norm shared among members of a group that permints cooperation among them. If member of the group come to expect that others will behave reliably and honesty, then they will come to trust one another. Trust is like lubricant that make the running of many group of organization more effident. ${ }^{23}$

Fukuyama meyatakan bahwa penyebaran nilai atau norma tidak sertamerta menjadi modal sosial apabila nilai atau

${ }^{22}$ Laksono, Runtuhnya modal..., hlm. 39.

${ }^{23}$ Francis Fukuyama, Trust: The Social Virtues and The Creation ..., hlm. 16 . 
norma termaksud tidak mengandung unsur kebenaran. Norma akan menjadi modal sosial apabila padanya terdapat unsurunsur yang substantif, misalnya; kebijakan, kebenaran berkata, kejujuran dan saling mempercayai.

Bagaimana hubungan antara modal sosial dengan program pendidikan sekolah di Indonesia? Menurut Sodiq A. Kuntoro banyak analisis yang disampaikan oleh para pakar pendidikan yang lebih mengutamakan pembaharuan pendidikan melalui peningkatan pengetahuan teknikal dan penyediaan peralatan teknologi modern dalam kegiatan belajar, tetapi secara fundamental kurang memperhatikan peningkatan kualitas sekolah melalui penggunaan modal sosial dan budaya masyarakatnya. ${ }^{24}$ Sekolah yang hanya menekankan pada pengetahuan teknikal dan pengembangan peralatan teknologi modern, kurang berkembang dan kurang memperoleh hasil yang maksimal. Upaya membangun sekolah yang baik sebenarnya sama dengan upaya membangun masyarakat yang baik.

Plato dalam Sodiq A. Kuntoro menyatakan bahwa kehidupan yang baik hanya dapat terjadi dalam masyarakat yang baik. ${ }^{25} \mathrm{Hal}$ ini berarti apabila masyarakatnya rusak maka kehidupan manusianya juga mengalami kerusakan. Oleh karena itu, sekolah sebagai miniatur masyarakat seharusnya dapat dijadikan sebagai tempat untuk mentransformasikan nilai-nilai yang positif, seperti kebaikan (goodness), kebenaran (truth) dan keindahan (beauty). Sekolah yang hanya mengedepankan prestasi akademik yang tidak dilandasi kekuatan nilai kebaikan (moral) hanya akan menghasilkan tamatan sekolah yang mudah merusak kehidupan bermasyarakat karena mengabaikan nilai-nilai dan budaya yang berkembang di masyarakat.

\section{Modal Sosial Madrasah di Indonesia}

Secara historis, madrasah di Indonesia sebagai institusi pendidikan Islam, memiliki berbagai keunikan yang dapat dijadikan sebagai modal sosial, walaupun di sisi lain juga memiliki banyak kelemahan. Hal ini sebagaimana dijelaskan oleh H.A.R.

\footnotetext{
${ }^{24}$ Kuntoro, Modal sosial...., hlm. 2.

${ }^{25}$ Kuntoro, Modal sosial..., hal 3.
} 
Tilaar bahwa pendidikan Islam di Indonesia, termasuk di dalamnya madrasah sebagai salah satu kekuatan budaya. Secara historis di masa penjajahan kolonial Belanda, sebagian besar pesantren sebagai embrio madrasah di Indonesia merupakan basis perlawanan penjajahan. ${ }^{26}$

Pasca kemerdekaan, peranan lembaga pendidikan Islam tidak mengalami perubahan yang signifikan. Hampir sebagian besar masih mempunyai komitmen untuk mentransformasikan nilai-nilai luhur yang dikembangkan para pendahulunya. Kesederhanaan hidup, kemandirian, semangat untuk mencari ilmu dan tidak pernah merasa puas terhadap ilmu yang diperoleh, mentransformasikan nilai religius dan nilai moral merupakan modal sosial yang dimiliki lembaga pendidikan Islam di Indonesia. Bahkan tidak sedikit para antropolog Indonesia, menjelaskan bahwa pendidikan Islam di Indonesia tidak dapat dipisahkan dengan sistem pendidikan nasional. Hal ini sebagaimana ditegaskan oleh Sjafri Sairin bahwa “... perkembangan sistem pendidikan Islam di Indonesia dari masa penjajahan sampai masa kini, tergambar dengan jelas bahwa sistem pendidikan Islam merupakan bagian yang tak terpisahkan dari sistem pendidikan nasional". ${ }^{27}$

Sjafri Sairin juga memberikan analisis terhadap perkembangan sistem pendidikan Islam di Indonesia dengan meng gunakan teori "model for" (model untuk) yaitu model yang berupa pola dari sistem pengetahuan gagasan dan cita-cita dari suatu masyarakat tentang bagaimana seharusnya dan sebaiknya. Sedangkan "model of " (model dari) adalah pola kehidupan yang hidup dalam realitas masyarakat yang kadang-kadang terkesan tidak jelas kaitannya dengan model for (model untuk). Menurut hasil analisisnya bahwa, sistem pendidikan Islam yang dikembangkan selama ini, belum sepenuhnya menggambarkan "model for" (model untuk), yang hadir dalam gagasan masyarakat muslim Indonesia.

Sejalan dengan perkembangan yang terjadi dalam komunitas masyarakat muslim Indonesia, sistem pendidikan di pesantren

${ }^{26}$ H.A.R Tilaar, Membenahi Pendidikan Nasional, (Bandung: Rineka Cipta: 2009), hlm. 77.

${ }^{27}$ Sjafri Sairin, Perubahan sosial Masyarakat Indonesia Perspektif Antropologi, (Yogyakarta: Pustaka Pelajar: 2001), hlm. 35. 
telah mengalami modifikasi. Selain mempertahankan beberapa sistem pendidikan yang menjadi karakteristik pesantren, lembaga ini mengikuti kecenderungan baru yang berkembang dalam sistem pendidikan Islam. Beberapa pesantren mendirikan lembaga pendidikan formal di dalamnya, sebut saja misalnya pesantren Tebuireng, pesantren Tambakberas, pesantren Denanyar, pesantren Paiton dan lain sebagainya.

Terdapat beberapa kelebihan dan kekurangan, ketika sistem pendidikan Islam sebagai modal sosial, mengadaptasi terjadinya perubahan yang berkembang di masyarakat. Kelebihannya adalah banyak lulusan pondok pesantren yang dapat berpartisipasi dalam kegiatan pembangunan yang lebih luas, dengan menjadi pegawai di berbagai institusi pemerintah maupun swasta. Namun kelemahannya juga perlu dikaji ulang, karena terdapat kecenderungan bahwa tradisi keilmuan "model for" di pesantren sudah sangat memprihatinkan. Sangat sedikit sekali orang yang bersedia untuk menjadi ulama, yang menjadi panutan masyarakat. Kondisi yang demikian tentu sangat mengkuartirkan, terutama bagi keberlangsungan menjaga tradisi nilai-nilai keislaman yang telah berkembang di masyarakat. Oleh karena itulah, perlu kiranya adanya pemberdayaan lembaga-lembaga pendidikan Islam, yang secara filosofis tidak kehilangan orientasinya untuk mengikuti "model for", tetapi dapat bertahan di tengah-tengah himpitan perubahan kehidupan masyarakat yang semakin tidak menentu karena pengaruh globalisasi dan arus informasi yang semakin tak terkendali.

Eksistensi madrasah dalam tradisi pendidikan Islam di Indonesia tergolong fenomena modern yang dimulai sekitar awal abad ke 20, karena madrasah lahir sebagai bentuk modernisasi sistem pendidikan Islam di pesantren. Modernisasi sistem pendidikan tersebut, meliputi; 1) upaya penyempurnaan sistem pesantren; 2) penyesuaian terhadap sistem pendidikan Barat; dan 3) menjembatani antara sistem pendidikan tradisional pesantren dengan sistem pendidikan modern Barat.

Abdul Wahid menyatakan bahwa pada umumnya madrasah didirikan oleh masyarakat (swasta) untuk memenuhi kebutuhan pendidikan agama anak-anak mereka. Oleh sebab itu, dukungan sosial masyarakat di mana madrasah tersebut berdiri pada umumnya kuat. Dukungan yang kuat dari masyarakat merupakan modal sosial yang seharusnya dapat dimanfaatkan secara 
maksimal oleh madrasah untuk mengembangkan berbagai program pendidikannya.

Modal sosial lain yang dimiliki madrasah adalah kedekatannya dengan budaya pesantren. Menurut Fatah Syukur, dalam konteks keindonesiaan, madrasah memiliki sejarah yang tidak bisa dilepaskan dengan pesantren. Sebagai lembaga pendidikan yang dilahirkan dari rahim pesantren, madrasah memiliki kesamaan visi atau bahkan merupakan " continuity" dari pesantren. Sistem pendidikan madrasah yang diperkenalkan oleh pesantren menitikberatkan pada keilmuan agama Islam di samping juga mengajarkan pengetahuan umum yang dapat digunakan untuk meningkatkan kepekaan terhadap masalah sosial dan lingkungan.

\section{E. Penutup}

Madrasah sebagai subsistem pendidikan Islam yang keberadaannya secara historis telah memperoleh dukungan kuat masyarakat. Dukungan masyarakat tersebut merupakan modal bagi madrasah. Kekuatan lain yang juga dimiliki oleh madrasah adalah adanya kultur pengembangan nilai-nilai atau norma-norma sebagai turunan kultur pesantren yang selama ini telah teruji kemampuan perannya sebagai penyeimbang pengaruh globalisasi maupun globalisasi, misalnya nilai kejujuran, keikhlasan, kemandirian, kesahajaan dan lain sebagainya.

Di sisi lain struktur dan relasi sosial yang berbentuk kelembagaan maupun individual baik yang bersifat internal maupun eksternal juga merupakan modal sosial yang seharusnya dapat dimanfaatkan untuk meningkatkan mutu pendidikan bagi madrasah. Sayangnya kebanyakan madrasah khususnya madrasah swasta masih belum memanfaatkan modal sosial yang dimiliki secara optimal. Sudah seharusnya dan saatnya modal sosial yang dimiliki madrasah tersebut dimanfaatkan dengan diawali pengidentifikasian terhadap modal sosial yang kemudian diberdayakan untuk kepentingan madrasah agar tujuan pendidikan yang ditetapkan dapat tercapai secara efektif dan efisien.

\section{Kepustakaan}

Agger, Ben. 2006. Teori Sosial Kritis: Kritik, Penerapan dan Implikasinya (terj.). Yogyakarta: Pustaka Pelajar. 
Azra, Azyumardi. 2000. Pendidikan Islam: Tradisi dan Modernisasi Menuju Milenium Baru. Ciputat: Logos.

Beilharz, Peter. 2002. Teori-Teori Sosial. Yogyakarta: Pustaka Pelajar.

Coleman, James S. 1994. Foundations of Social Theory. Harvard University: The Belknap Press.

Daulay, Haidar Putra. 2009.Pemberdayaan Pendidikan Islam di Indonesia. Bandung: Rineka Cipta.

Sllis, Edward. 2010. Total Quality Managemen in Education, Manajemen Mutu Pendidikan Terj. Yogyakarta: Itcisod.

Fakih, Mansur. 2001. Runtuhnya Teori Pembangunan dan Globalisasi. Yogyakarta: Insist Press.

Fatah, Syukur. 2002. Madrasah di Indonesia: Dinamika, Kontinuitas dan Problematika, Yogyakarta: Pustaka Pelajar.

Field, John. 2012. Modal Sosial (Terj). Bantul: Kreasi Wacana.

Friedmann, John. 1992. Empowerment: The Politics of Alternative Develepment. Cambridge: Blackwell Publisher.

Fuad Yusuf, Choirul. 2006. Isu-Isu Sekitar Madrasah. Jakarta: Puslitbang Pendidikan Agama Dan Keagamaan. Badan Litbang Dan Diklat Departemen Agama RI.

Fukuyama, Francis. 1996. Trust: The Social Virtues and The Creation of Pros-Perity. London: Penguin Book.

Irene Astuti Dwiningrum, Siti. 2009. Desentralisasi Pendidikan dan Dinamika Sosial. Yogyakarta: Pascasarjana Sosiologi UGM.

------, 2011. Desentralisasi dan Partisipasi Masyarakat dalam Pendidikan. Yogyakarya: Pustaka Pelajar.

Karl, M. 1995. Women and Empowerment: Participation and Decision Making. London: Zed Books Ltd.

Komite Reformasi Pendidikan. 2001. Reformasi Pendidikan Nasional. Jakarta: Departemen Pendidikan Nasional.

Kotter, John. P. 1996. Leading Change. Massachussetts: Harvard Busi-Ness School Press.

Kuntoro, Sodiq. A. 2012. Modal Sosial dan Budaya bagi Peningkatan Kualitas Pendidikan Persekolahan. Yogyakarta: Program Pascasarjana Universitas Negeri Yogyakarta.

Leksono, S. 2009. Runtuhnya Modal Sosial, Pasar Tradisional: Perspektif Emik Kualitatif. Malang: Citra Malang. 
M. Dahlan, Pius A Partanto. 1994. Kamus Ilmiah Popular, Surabaya, ARKOLA.

Sairin, Sjafri. 2001. Perubahan Sosial Masyarakat Indonesia Perspektif Antropologi. Yogyakarta: Pustaka Pelajar.

Sergiovanni, Thomas J. 1993. Building Community in School. San Fran-Cisco: Jossey-Bass Publisher.

Tilaar, H.A.R. 2002. Perubahan Sosial dan Pendidikan: Pengantar Paedagogik Transformatif untuk Indonesia. Jakarta: Grasindo

------, 2004. Paradigma Baru Pendidikan Nasional. Bandung: Rineka Cipta.

------, 2006. Standarisasi Pendidikan Nasional. Bandung: Rineka Cipta.

------, 2009. Membenahi Pendidikan Nasional. Bandung: Rineka Cipta.

------, 2009. Kekuasaan dan Pendidikan: Manajemen Pendidikan Nasional dalam Pusaran Kekuasaan. Bandung: Rineka Cipta.

------, 2011. Paedagogik Kritis: Perkembangan, Substansi, dan Perkembangannya di Indonesia. Bandung: Rineka Cipta.

Tilaar, H.A.R \& Riant Nugroho. 2008. Kebijakan Pendidikan: Pengantar untuk Memahami Kebijakan Pendidikan sebagai Kebijakan Publik. Yogyakarta: Pustaka Pelajar.

Wahid, Abdul. 2002. Manajemen Berbasis Madrasah: Ikhtiyar Menuju Madrasah yang Mandiri. Yogyakarta: Pustaka Pelajar.

Zamroni. 2007. Pendidikan dan Demokrasi dalam Transisi: Prakondisi Menuju Era Globalisasi. Jakarta: PSAP Muhammadiyah.

------, 1992. Pengantar Pengembangan Teori Sosial. Yogyakarta: Tiara Wacana

Zarkasyi, A. Syukri. 2005. Manajemen Pesantren: Pengalaman Pondok Modern Gontor. Ponorogo: Trimurti Press. 
